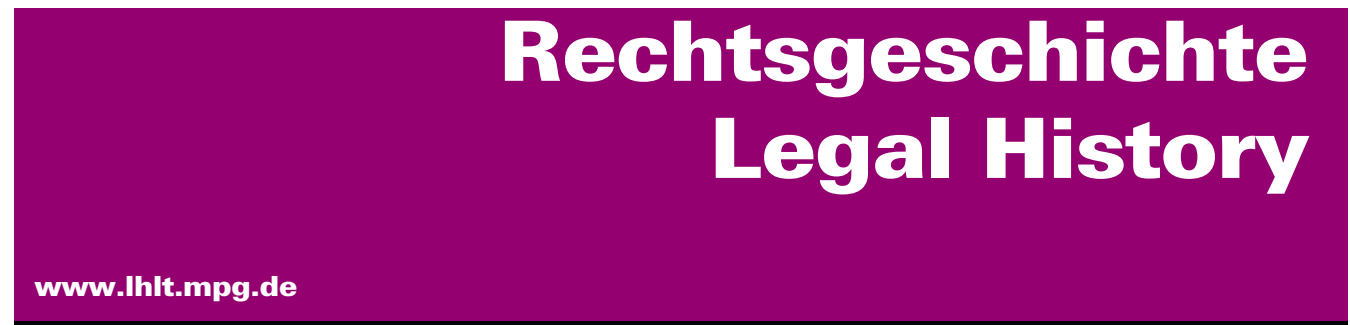

http://www.rg-rechtsgeschichte.de/rg29

$\operatorname{Rg} 292021 \quad 355-357$

Zitiervorschlag: Rechtsgeschichte - Legal History Rg 29 (2021)

http://dx.doi.org/10.12946/rg29/355-357

\title{
Karla L. Escobar H.*
}

\section{Gestionar la multiculturalidad y el arte de pensar la indigeneidad}

[Managing Multiculturalism and the Art of Thinking Indigeneity]

\footnotetext{
* Max Planck Institute for Legal History and Legal Theory, Frankfurt am Main, escobar@lhlt.mpg.de
} 
Karla L. Escobar H.

\section{Gestionar la multiculturalidad y el arte de pensar la indigeneidad*}

Managing Multiculturalism es el producto de un ejercicio etnográfico, de más de cincuenta años, hecho por la antropóloga Jean E. Jackson con diferentes comunidades indígenas en Colombia. A partir de una reflexión juiciosa sobre los conceptos de identidad, multiculturalismo y neoliberalismo, Jackson se embarca a analizar el proceso de construcción de la »indigeneidad« en la segunda mitad del siglo XX en Colombia. Tal ejercicio analítico lo hace a partir de diferentes estudios de caso.

El trabajo de Jackson, profesora emérita de la facultad de antropología del Massachusetts Institute of Technology, inicia en 1968, en la región amazónica colombiana - específicamente con los pueblos tucanos - y después se desplaza a otras regiones del país. Esta narrativa no busca hacer un ejercicio comparativo, sino más bien, dar cuenta de las transformaciones en espacio y tiempo que la categoría de »indígena" tuvo en esos cincuenta años y los debates alrededor de ella. El ejercicio etnográfico de Jackson coincide, además, cronológicamente con el proceso de configuración del movimiento indígena en Colombia, paralelismo usado por la autora de forma magistral para lograr entrelazar sus reflexiones sobre las sociedades estudiadas con un ejercicio auto-etnográfico el cual le permite dar cuenta de la plasticidad de las categorías que estudia.

El trabajo está dividido en seis capítulos, incluida la introducción. El primero introduce al lector en los debates contemporáneos sobre multiculturalismo, identidad y neoliberalismo en tanto claves para comprender las distintas formas en las que se configura la indigeneidad a lo largo de la segunda mitad del siglo XX. Seguidamente, en el siguiente capítulo, hace un ejercicio de contextualización histórica respecto al proceso de configuración del movimiento indígena a finales de los 60s, sus transformaciones y su papel en la constituyente en 1991.
Una vez hecha esta contextualización histórica y teórica, la autora pasa a analizar, en los capítulos 2 y 3, los casos que han estado en el foco de su investigación: las sociedades amazónicas, específicamente las complejidades en los procesos de creación de la »indigeneidad « para los Tucanos y para los Nukak-Makú, particularmente después de 1988 cuando estos últimos "aparecieron« por primera vez en el ámbito nacional. El análisis se centra en la relación de estos pueblos con múltiples actores: el movimiento indígena nacional, las ONGs, los funcionarios del gobierno, los antropólogos y las Iglesias católica y evangélica, entre otros. Igualmente, analiza las tensiones, discusiones y divisiones dentro de los mismos Tucanos (incluídos los miembros del Consejo Regional Indígena del Vapupés-CRIVA), así como las tensiones entre Tucanos y los Nukak-Makú.

En el capítulo cuatro, la autora regresa al foro nacional para detallar otro tipo de sinergias y tensiones que se producen dentro de las diferentes organizaciones del movimiento indígena a nivel nacional, así como las tensiones que se producen entre estas y los organismos estatales en el marco de la Jurisdicción Especial Indígena, creada en la Constitución de 1991. Para ello, la autora analiza tres casos concretos: las protestas de activistas indígenas en 1996, la creación y el debate respecto a la distribución de la de la gaseosa a base de hoja de coca »Coca-Seck « y los juicios contra los líderes indígenas Jesús Piñacué y Francisco Gembuel que tuvieron amplia difusión en medios a finales de los años 90. El análisis de estos casos buscó problematizar las difusas fronteras entre derechos, prácticas culturales y posicionamientos políticos en tanto elementos centrales para la construcción de la indigeneidad en contexto.

Finalmente, en el último capítulo, la autora lleva la pregunta por la indigeneidad a un nuevo contexto: el de los pueblos que han llevado de

* Jean E. Jackson, Managing Multiculturalism. Indigeneity and the Struggle for Rights in Colombia, Stanford: Stanford University Press 2019, 328 p., ISBN 978-1-5036-0622-7 
forma reciente procesos de re-indigenización exitosos (aunque muy disputados y conflictivos). Estudia, así, los casos de los Yanacona en el Huila, el Muisca en Bogotá y el cabildo multiétnico en el Putumayo. La autora se esfuerza aquí nuevamente por caracterizar en detalle la complejidad de estos procesos y señala la relevancia de comprender la »indigeneidad « desde el eclecticismo y el dinamismo cultural, en oposición a la idea de una indigeneidad inmutable, "pura « $\mathrm{o}$ »incorrupta « que tiende a defenderse en los ámbitos institucionales.

Ahora bien, ¿por qué el trabajo de Jean E. Jackson es relevante para los historiadores del derecho? Quiero destacar tres puntos.

En primer lugar, el trabajo de Jackson es relevante para aquellos interesados en comprender el derecho desde las prácticas y desde los ejercicios comunicativos asociados a ellas. Si bien la autora no hace un estudio detallado de la legislación debido a que se sale de su mirada disciplinar - sí da cuenta de la interdependencia entre derecho, política y prácticas culturales dando cuenta de la complejidad de las relaciones que se entretejen entre estas esferas aparentemente aisladas.

Al respecto, la autora hace un importante señalamiento que considero clave y que abre varios caminos de reflexión para la Historia del Derecho contemporánea. Así, dice: »Rights are first transformed in struggles in courts, in the media, and on blocked highways - and then transformed again in such forums as mandated round tables in which they are discussed, negotiated, and instantiated or refuted. While the rights are defined by the laws, regulations, and accords that put them on paper, they become real only in the field of action« (170).

Si bien esta idea no es necesariamente nueva para la Historia del Derecho ni para los estudios sociales en derecho, sí lo es la aproximación metodológica que asume para analizar tales dinámicas. La forma en la que Jackson construye su narrativa nos recuerda la importancia de problematizar las categorías - usualmente dicotómicas - a partir de las cuales se construye el conocimiento histórico sobre lo jurídico. La autora no solamente invita a prestar mayor atención a la forma en la que se entreteje teoría y práctica, ya sea en la forma de leyimplementación o teoría científica-práctica cultural, sino que también se detiene a comprender las formas contextuales en las que lo teórico se produce y lo práctico se pone en escena. Así, logra abordar analíticamente las contradicciones, conflictividades e incoherencias propias del derecho, en tanto espacio tradicionalmente descrito como estructurado, lógico y coherente.

En segundo lugar, para aquellos quienes concebimos el derecho como una red de ejercicios comunicativos complejos en el que múltiples actores participan sobre relaciones de poder múltiples y superpuestas, resulta relevante involucrar en el análisis una gran cantidad de interlocutores, como bien lo hace la autora en cada caso que analiza. Jackson logra incluir en su análisis diferentes actores estatales, ONGs, antropólogos, medios de comunicación, pueblos, autoridades indígenas, etc., además de dar cuenta de las divisiones existentes dentro de estos grupos de actores y la forma dialógica y a la vez conflictiva en la que los diferentes procesos de construcción de la indigeneidad se llevan a cabo en medio de todas estas voces. Aunque su objeto de reflexión no es el derecho, su mirada sí le permite a los historiadores del derecho, comprender mejor lo »indígena« en tanto categoría jurídica y, sobre todo, a rastrear la plasticidad de tal categoría.

En relación con ello, otro elemento clave que el trabajo de Jackson nos ayuda a pensar, es la importancia de la puesta en escena o performance de la indigeneidad a partir de los diferentes públicos que consumen la alteridad indígena. Para los historiadores del derecho interesados en comprender cómo otras normatividades participan en la creación del derecho, estudiar las formas en las que la indigeneidad es puesta en escena en diferentes foros también abre importantes rutas de reflexión. Las puestas en escena en todos los casos analizados por Jackson no sólo están filtradas por códigos culturales - como es de esperarse -, sino también por principios económicos, morales, intereses políticos, estéticos y, por supuesto, aquellos construidos por la violencia.

Finalmente, considero que el trabajo de la autora le permite al historiador del derecho retomar discusiones que teóricamente están supuestamente superadas como, por ejemplo, los debates alrededor del concepto de »cultura«. Como lo muestra la autora, aunque ríos de tinta se han escrito sobre el concepto de cultura desde múltiples disciplinas y pareciera que la discusión está agotada, su conceptualización sigue siendo un problema fáctico, a partir de lo cual los funcionarios toman decisiones, reparten recursos, formulan proyectos y por supuesto, legislan y juzgan. Así pues, si bien a nivel académico, desde hace muchos años hay claridad respecto a la plasticidad de la mayoría de las 
categorías con las que trabajamos, son particularmente los gobiernos, en especial sus ramas judiciales y legislativas quienes presumen la existencia de categorías cerradas y claramente definidas. En este sentido, es urgente una historia del derecho que de cuenta de esta plasticidad en términos jurídicos y, debido a esto, el texto de Jackson puede abrir múltiples caminos de reflexión para nuestra disciplina.

\section{Ron Harris}

\section{Land Law Meets the Sea*}

Humans are terrestrial mammals as the introduction to this intriguing volume reminds us. Their normative orders were shaped on the land. Applying human law to the seas and oceans of this planet was never a straightforward process. Two historical developments placed new challenges and directions on early modern Europe's legal encounters with the seas. The Westphalian order that emerged out of the long religious wars centralized concepts of sovereignty, borders, citizenship and nation states - all land-based concepts. The European expansion through the Atlantic and Indian Oceans to the Americas and Asia gave rise to two new sets of legal problems: the first relating to the encounters between sovereign European states on the high seas around the globe, and the second involving encounters with non-European polities and laws in and around newly annexed islands and seaboards across these oceans. The book chapters deal with various interplays of these reformulated sets of problems in the early modern era.

This volume was edited by two prominent historians whose approaches cross each other in a manner that is highly promising for legal historians. Rosenthal is an emerging historian of the Atlantic World in the first age of revolution. His interdisciplinary approach combines spatial studies, script analysis, and law. Benton is one of the leaders of the historical turn in international law. She is a historian of the legal history of the British Empire and empires in general from a global perspective. The volume they edited is the outgrowth of a conference held in the Huntington Library in Pasadena, California, in 2016. The volume aims at advancing our understanding of how the maritime world contributed to the early modern era's global transformation. It demonstrates the complex relationship between humans and seas, and between terrestrial and maritime spaces.

For the sake of the legal historian readers of Rechtsgeschichte - Legal History, rather than conventionally reviewing the chapters one-by-one in the order they appear in the book, or based on the themes suggested by the editors in the Introduction, I'll address the question of what legal historians can gain from reading this book. To this end, the chapters in the volume will be allocated into three groups: first, chapters that do not deal at all with law but for which I'll suggest possible links to legal history; second, chapters that make preliminary extension of the non-legal analysis into law and for which I will suggest how they can be used and expanded on by legal historians; and third, chapters that deal head-on with law. As usual, this division is not always crystal clear.

In Chapter 1, Carla Rahn Phillips examines the reasons for serving as crew aboard ships given the extreme risks and hardships involved. There was overlap with and switches taking place between naval service and merchant marine crews as well as officers all the way up to the 18 th century. Reasons for going to sea included family traditions, economic incentives, legal conscription requirement, and violent coercion. This chapter lays the founda-

* Lauren Benton, Nathan Perl-

Rosenthal (eds.), A World at Sea:

Maritime Practices and Global

History, Philadelphia: University

of Pennsylvania Press 2020, 267 p.,

ISBN 978-0-8122-5241-5 